\title{
О словотворчестве российских и польских интернет-пользователей в эпоху глобальной интернационализации
}

\section{On the word creation of Russian and Polish Internet users in the era of global internationalization}

\begin{abstract}
The article deals with the evolution of word-formative types of nouns with new international formants -инг/-ing, -(о)голик/-(o)holik, -завp/-zaur, -оид/-oid that can express the complex concepts of attributive and contextual content. The composition of a new type of words with morphemes -инг/-ing, -(о)голик/-(o)holik,-завp/-zaur corresponds to a historical drift in the formation of analytic and agglutinative lines in the Russian and Polish languages.
\end{abstract}

Keywords: globalization, internationalization, Englishization, word-formation, hybrids

Elena Koriakowcewa, Uniwersytet Przyrodniczo-Humanistyczny w Siedlcach, Siedlce - Polska, elena.koriakowcewa@uph.edu.pl, ORCID ID: https://orcid.org/0000-0003-0701-1506

\section{Введение}

В эпоху глобальной интернационализации в Интернете и масс-медиа формируется глобальная культура, базирующаяся на специфическом „игровом" мировоззрении, при котором важны лишь те духовные ценности, которые удовлетворяют потребности „homo ludens, человека играющего” (cp. Huizinga). Всемирное распространение глобальной культуры связано с беспрецедентным экспансионизмом английского языка - Englishization (Kachru 249). Одним из следствий Englishization, глобальной англизации, является билингвоанглизация (см. Kabakči 86), т. е. развитие местно-английского билингвизма, который распространяется внутри локальных сообществ, в том числе славянских стран, вошедших в „расширяющийся круг английского языка" (the Expanding Circle - термин Браджа Качру). В структуре местно-английского билингвизма один из элементов вариабелен (родной язык местного говорящего сообщества), а второй универсален (английский язык 
как средство создания глобальной коммуникативной среды в двух взаимосвязанных пространствах - реальном и виртуальном).

Билингвоанглизации и культурной глобализации более всего подвержены коммуниканты 18-40 лет, принадлежащие к поколениям „цифровых иммигрантов” и „цифровых туземцев” (см. Prensky). Лингвокреативные представители этих „сетевых поколений”, отличающиеся пластичностью мышления и податливостью психики, способны к быстрому кодовому переключению мышления, склонны к языковой игре и гибридному словообразованию в ходе интернет-коммуникации (см. Vinogradova).

Речевое поведение „сетевых аборигенов”, как и процессы деривационной гибридизации, происходящие в современной интернет-среде, невозможно описать в рамках одной статьи, поэтому мы проанализировали лишь некоторые проявления словотворчества российских и польских интернавтов, обусловленные глобальной интернационализацией и билингвоанглизацией, сопоставляя русские и польские неодериваты с новыми интернациональными формантами - двумя аффиксами английского и англо-американского происхождения (-инг/-ing, -(o)голик/-(o)holik) и двумя „евролатинскими” аффиксами (-завp/-zaur, -oud/-oid). Эти форманты, известные в 16 европейских языках (см. Görlach), являются мобильными транслокальными оперативными словообразовательными ресурсами (ср. Blommaert, Dong).

Источниками языкового материала послужили российские и польские интернет-форумы и блоги, а также интерактивные интернет-словаpи, размещенные на сайтах www.slovonovo.ru, http://nowewyrazy.uw.edu. pl. Обращение к поисковым системам Яндекс и Google обеспечило доступ к неограниченному объему текстов, что значительно упростило выявление и сравнительный анализ русских и польских гибридных неодериватов.

\section{Гибридные неодериваты с формантами -инг/-ing}

По данным Анатолия И. Дьякова и Елены В. Скворецкой (D'âkov, Skvoreckaâ 181), в современном русском языке функционируют более 1500 лексических единиц с финалью -инг, этимологически восходящей к суффиксу английского герундия -ing. Это достаточно давно известные слова из обиходно-бытовой сферы (лифтинг, тримминг); музыкальные термины (скримминг, шугейзинг); спортивные термины (прессинг, рафтинг); наименования правонарушений (фишинг, шоплифтинг); экономические термины (мерчендайзинг, франчайзинг); научные термины (инбридинг, кроссбридинг). К концу XX века группу существительных с финалью -инг пополнили компьютерные термины (апгрейдинг, рефакторинг, эгосерфинг). В XXI веке появились 
варваризмы-транспланты, обозначающие концепты интернет-коммуникации, ср.: блогинг, инстаграминг, интернетинг, лайкинг, скайпинг, твиттеринг, троллинг, фейсбукинг, форуминг, чатинг, а также польск. blogging/ bloging, czating, fejsbuking, instagraming, lajking, skajping, trolling, twittering.

Зная из опыта изучения английского языка о суффиксе герундия -ing, а также имея в словарном запасе англицизмы с этой морфемой, лингвокреативные русофоны осознают ее процессуальное значение и в ходе языковой игры используют как своеобразный эмоционально-экспрессивный суффиксальный терминоэлемент. Суффиксальный формант -инг - автономный носитель процессуального значения - проявил свой словообразовательный потенциал в медиатекстах и молодежном сленге, где с его помощью были созданы гибридные экспрессивные отыменные имена действия типа балетинг 'исполнение балетных партий', гулянинг 'гулянка', каякинг 'перемещение на каяках', крысинг 'охота на крыс', крышинг 'танцы на крышах', пьянинг 'пьянка', собачинг 'отстрел бездомных собак', уазинг 'путешествие на внедорожнике УАЗ’ и др. (см. Korâkovceva 84-87).

„Сетевые аборигены” не только воспроизводят эти сленгизмы в ходе интернет-общения, но и создают новые имена процессов, присоединяя терминоэлемент -инг к основам абстрактных, конкретных, собственных и нарицательных существительных, ср.: баба $\rightarrow$ бабинг 'флирт', вининг 'распитие вина', водопадинг 'преодоление водопадов', водкинг 'распитие водки', глинтвейнинг 'приготовление глинтвейна', идиотинг 'превращение в идиота', Ленин $\rightarrow$ ленининг 'коллекционирование фотографий со статуями В. И. Ленина', магазин $\rightarrow$ магазининг 'посещение магазинов', путинг 'агитация за кандидата Путина'. Ср. также: базаринг, волейболинг, дебатинг, дебилинг, жабинг, каруселинг, комплиментинг, кочмаринг, лёжинг, магазининг, моточиклинг, мужикинг, параноинг, пляжинг, рынкинг, сарделинг, сосисинг, халтуринг, фанеринг, флиртинг, шашлыкинг, шизофренинг, шлюхинг и др.

Польскому языку англицизмы с финалью -ing известны с начала XX века, но словообразовательная активность этой финали была практически равна нулю (см. Waszakowa 116). В последние же пять лет под влиянием СМИ среди части польской молодежи возникла мода на „ингование” и на интернет-форумах появились такие шутливо-иронические гибридные дериваты, как balkoning 1. 'прыжки туристов с балконов гостиницы в бассейн', 2. 'отдых на балконе', 3. 'выгуливание собак и кошек на балконе', browaring 'питье пива' $\leftarrow$ browar, kawing 'питье кофе' $\leftarrow$ kawa, kietbasing 'поджаривание колбасы на гриле' $\leftarrow$ kietbasa, kocing 'лежание на одеяле' $\leftarrow$ koc, kompoting 'питье компота' $\leftarrow$ kompot, kościoling 'посещение костела' $\leftarrow$ kościót, leżaking 'отдых на лежаке', tomżing 'питье пива марки Ломжа' $\leftarrow$ Łomża, piwing 'питье пива' $\leftarrow$ piwo, plażing 'лежание на пляже' $\leftarrow$ plaża, spacering 
'хождение на прогулки' $\leftarrow$ spacer, wódking 'питье водки' $\leftarrow$ wódka, а также bazaring, foteling, grobing, idioting, imprezing, mandating, telewizoring, urloping, wstyding и др.

Создан сайт https://ingi.wadi.pl, на котором размещены около ста гибридных дериватов с формантом -ing (в основном это отыменные имена процессов), напр.: adrenalining 'uprawianie sportów podnoszących poziom adrenaliny'; agresing 'napastliwe, agresywne zachowanie'; chatturing 'lekceważący stosunek do wykonywanej pracy'; dywaning 'leżenie lub siedzenie na dywanie; inaczej też trzepanie dywanów'; kanaping 'wygodne siedzenie lub leżenie na kanapie'; suszing 'zajadanie się suszi'; urloping 'pobyt wypoczynkowy na urlopie'; wining 'picie wina, w przeważnie w samotności' ${ }^{\prime}$ и др. (Ingi.wadi.pl, электронный ресурс).

Не исключено, что рост словообразовательной активности суффиксов -инг/-ing будет способствовать расширению деривационной базы процессуальных имен в русском и польском языках, так как с помощью этих новых формантов не только восполняются системные пробелы, но и создаются яркие эмотивные стилистические эффекты.

\section{Гибридные неодериваты с формантами -завр/-zaur}

„Евролатинский” аффиксальный терминоэлемент -saurus/-saur/-завp/-

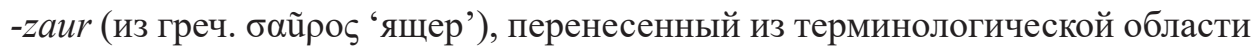
в эмоционально-экспрессивную, используется для создания стереотипного образно-ассоциативного комплекса, передающего концепт „примитивность, отсталость". Этот метафорический терминоэлемент стал словообразовательно активным благодаря прецедентным американским медийным текстам, в которых фигурировали гибридные неодериваты типа Bidenosaur, Clintonosaur, Obamosaur, Paulosaur (The Spoof!, электронный ресурс), созданные журналистами с целью по-новому структурировать концепт „отсталость" применительно к политическим лидерам, а также к их адептам. Новый способ словесной эквилибристики был взят на вооружение российскими и польскими журналистами: с помощью аффиксов -завp/-zaur, употребленных в переносном значении 'отсталый, примитивный человек', были образованы зооморфные метафорические инвективы, указывающие на приверженцев государственных и политических деятелей России и Поль-

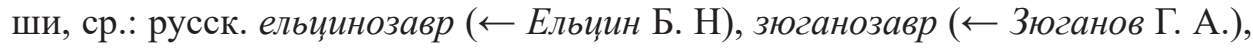

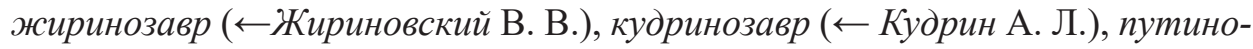

\footnotetext{
${ }^{1}$ Авторская пунктуация и орфография сохранены - Е. К.
} 


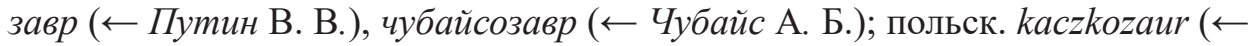
Kaczyński - Качиньски Ярослав), lepperozaur ( $\leftarrow$ Lepper - Лепnер Анджей), rydzykozaur ( $\leftarrow$ Rydzyk - Pbıдзик Тадеуш), tuskozaur ( $\leftarrow$ Tusk - Tyск Дональд).

По аналогии с этими инвективами, появившимися на сайтах влиятельных российских и польских газет, стали создаваться ругательства в молодежных сленгах, первоначально в русском, а затем и в польском. Среди ругательств, образованных русофонами с помощью аффикса -завр, можно выделить: 1) инвективные обозначения недостатков умственного развития (әлупозавр 'глупый человек', дурозавр 'очень глупый человек', колхозавр 'умственно ограниченный человек из района, деревни, села', лохозавр 'глупый, наивный человек', тупозавр 'тупой человек'); 2) инвективные обозначения отрицательных черт характера и асоциальных моделей поведения (быдлозавр 'примитивный, аморальный человек', дерьмозавр 'подлый человек', очкозавр 'трус, неспособный сопротивляться преступникам', хамозавр 'примитивный хам', шлюхозавр 'развратный мужчина'); 3) инвективные обозначения внешности человека (жирнозавр 'очень толстый человек', толстозавр 'толстый человек'); 4) инвективные обозначения отклонений в психическом здоровье, ср.: психозавр 'психически ненормальный человек', шизозавр 'психически деградировавший человек’. Обращение к поисковым системам Яндекс и Google показало, что эти гибридные дериваты активно функционируют в виртуальном пространстве.

В современной русскоязычной интернет-коммуникации пополняются неодериватами первая, вторая и четвертая группы инвектив, ср.: глупозавр, дебилозавр, идиотозавр, кретинозавр, наивнозавр, олигофренозавр, тупозавр (1); бабозавр 1. 'старый бабник', 2. 'злая женщина', грубозавр, стервозавр, трахозавр 'старый бабник, сексуальный маньяк', хамлозавр, чудакозавр 'странный, чудаковатый человек' (2). В четвертой группе инвектив появились названия людей, ставших психически ненормальными из-за своего давнего пристрастия к Инстаграму, Интернету, Твиттеру и Фейсбуку (инстаграмозавр, интернетозавр, нетозавр, твиттерозавр, фейсбукозавр). Группу инвективных обозначений внешности пополнил лишь один гибридный дериват - салозавр $(\leftarrow$ сало), использованный в контексте как средство самоуничижения: „[...] я салозавр [...]” (см. Harbor.ru, электронный ресурс).

Базисными семантическими признаками, формирующими значения ругательств, созданных российскими интернавтами с помощью морфемы-терминоида -завр, являются „интеллект” (глупость), „характер” (злобность), „моральные качества” (подлость) и „поведение” (отклонения от социальных норм), „Психическое здоровье”, „внешность” (физические недостатки - тучность). Эти же базисные семантические признаки являются строительным 
материалом для образования польских инвектив с изофонным формантом -zaur, немногочисленных и малоупотребительных по сравнению с русскими, ср.: 1) „низкий интеллект”: głupozaur, durniozaur, debilozaur, kretynozaur, idiotozaur; 2) „недостатки характера”, „отклонения от социальной нормы поведения": aferozaur 'скандалист', babozaur 'злая женщина', dziwnozaur “странный человек’; 3) „Психическое нездоровье”: psychozaur; 4) „внешность” (физические недостатки - тучность): brzuchozaur 'неухоженная брюхатая женщина, беременная', grubozaur 'толстый человек' .

Анализ гибридных неодериватов, образованных с помощью „евролатинских" аффиксов -завр, -zaur, употребленных в метафорическом значении, показывает, что для российских и польских интернавтов наиболее нетерпимым пороком является низкий интеллект. Инвективы, образованные с помощью формантов -завр, -zaur, содержат в своей структуре адъективные и субстантивные мотивирующие основы, называющие признаки умственной неразвитости: 1) неспособность к здравому рассуждению (русск. глупозавр, дурозавр, тупозавр; польск. głupozaur, durniozaur); 2) неспособность быстро и правильно оценить ситуацию (русск. лохозавр, наивнозавр, чудакозавр; польск. dziwnozaur); 3) патологические отклонения в психике (русск. дебилозавр, идиотозавр, кретинозавр, олигофренозавр; польск. debilozaur, kretynozaur, idiotozaur).

\section{Гибридные неодериваты с формантами -оид/-oid}

В конце XX века масс-медиа США стали также „поставщиками” пейоративных дериватов, созданных с помощью суффиксального терминоэлемента -oid со значением подобия (ср. греч. عĩ்o ‘ 'вид, образ'). Эти гибридные дериваты, образованные от имен политиков, обозначали их умственно недоразвитых адептов-подражателей, ср.: bushoid (Bush), Clintonoid $(\leftarrow$ Clinton), Obamoid $(\leftarrow$ Obama), Trumpoid $(\leftarrow$ Trump); ,Another Clintonoid to become an Obamoid. Not surprised" (Free Republic, электронный ресурс).

Новая словообразовательная модель „оним + формант -oid (-оud)” была заимствована российскими и польскими журналистами, в текстах которых появились гибридные дериваты - пейоративные названия адептов государственных и политических деятелей, ср.: русск. ельцииноид ( $\leftarrow$ Ельцин), жириноид $(\leftarrow$ Жириновский), зюганоид $(\leftarrow$ Зюганов), медведоид $(\leftarrow$ Мед-

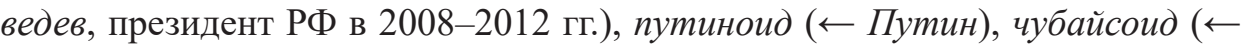
Чубайc); польск. giertychoid ( $\leftarrow$ Giertych Roman, председатель партии „Лига польских семей”), kaczoroid $(\leftarrow$ Kaczor $=$ Kaczyński), lepperoid $(\leftarrow$ Lepper $)$, tuskoid ( $\leftarrow$ Tusk). 
На рубеже XX-XXI вв. под влиянием медийных текстов в русском молодежном сленге возникли инвективы - гибридные дериваты с формантом -оид, созданные на базе названий людей, имеющих отклонения в психике (дебилоид, дауноид, имбечилоид, кретиноид, иизоид 'человек, ведущий себя подобно шизофренику'), а также зоонимы, обладающие коннотативными компонентами, придающими лексическим значениям грубую экспрессию презрения и пренебрежения (бараноид, быкоид, гориллоид, жабоид, кабаноид, козлоид, крысоид, скотиноид). Эти этические пейоративы активного неуважения употребляются российскими интернавтами обычно на форумах, см.: „Откуда ж вы лезете, имбецилоиды? Поколения имбецилоидов никакое государство не переживет!" (Pikabu, электронный ресурс); „Кабаноиды и бараноиды считают себя сталинцами” (17marta.ru, электронный ресурс).

Инвективы - гибридные неодериваты с интернациональным формантом -оид - в интернет-коммуникации обозначают, как правило, внутреннюю несостоятельность человека. Исключение составляет жирноид 'очень тучный человек’: „Жирноид буквально ревел...” (Filisof.Livejournal, электронный ресурс).

В польских интернет-ресурсах нами была обнаружена лишь одна зооморфная инвектива с формантом -oid-matpoid (от matpa, ср. русск. гориллоид). Анализ данных, полученных с помощью поисковой системы Google, показал, что в агрессивном дискурсе польских интернавтов используются в основном пейоративы с формантом -oid, образованные от названий людей, имеющих отклонения в психике: debiloid, kretynoid (ср. русск. дебилоид, имбецилоид, кретиноид).

\section{Гибридные неодериваты с формантами -(o)zолик, -(o)holik}

Следствием глобальной англизации и готовности постмодернистского общества скандализироваться по любому поводу является рост словообразовательной активности структурного элемента -(o)holic, обозначающего человека, который испытывает патологическую зависимость от чего- или кого-либо. Этот элемент вычленился из структуры существительного alcoholic, по аналогии с которым, по данным Merriam-Webster Dictionary, в 1968 году был образован американизм workaholic (вариант - workoholic). Новый структурный компонент -(o)holic очень быстро прошел процесс суффигирования, превратившись в интернациональную словообразовательную морфему - суффиксоид, ставшую продуктивной во многих европейских языках, в том числе русском и польском. 
Обращение к поисковой системе Яндекс показало, что словопроизводство с помощью форманта -(о)голик чрезвычайно активно в речи российских интернавтов: в последние годы образовано более 140 гибридных неодериватов с общим словообразовательным значением 'лицо, испытывающее патологическую зависимость от чего- или кого-либо'. Бо́льшую часть неодериватов с финалью -голик составляют названия лиц, находящихся в патологической зависимости от своих увлечений, страстей и пороков, ср.: автомобилеголик, бабоголик, битлоголик, блогоголик, брендоголик, гитароголик, гневоголик, деньгоголик, диетоголик, дискоголик, евроголик, женоголик, игроголик, интригоголик, казиноголик, карьероголик, киноголик, книгоголик, компьютероголик, косметикоголик, котоголик, кошкоголик, курортоголик, ласкоголик, любовеголик, медиаголик, мелодрамоголик, мобилоголик, модоголик, мореголик, мотоголик, наркоголик, наукоголик, нетоголик, никотиноголик, отдыхоголик, парфюмероголик, пёсоголик, пляжеголик, победоголик, подаркоголик, политикоголик, порноголик, поттероголик, программистоголик, психоголик, рекламоголик, романоголик, рифмоголик, рыбалкоголик, рэпоголик, сериалоголик, сетеголик, смехоголик, собакоголик, спортоголик, стихоголик, страхоголик, стрессоголик, сумкоголик, табакоголик, танщеголик, телеголик, тестоголик, тряпкоголик, туроголик, туфлеголик, фильмоголик, флиртоголик, фотоголик, футбоголик, шлюхоголик, экстремалоголик, эротоголик и др.

Растет число неодериватов, называющих лиц, патологически зависимых от продуктов питания, блюд и напитков, ср.: авокадоголик, бананоголик, борщеголик, булкоголик, виноголик, вискоголик, водкоголик, едоголик, йогуртоголик, какаоголик, картофелеголик, квасоголик, кефироголик, колбасоголик, конфетоголик, коньякоголик, кофеголик, макароноголик, макоголик, мармеладоголик, мёдоголик, молокоголик, мясоголик, нектароголик, овощеголик, пепсиголик, пивоголик, пищиаголик, пищеголик, рыбоголик, салатоголик, сахароголик, сокоголик, супоголик, сушиголик, сыроголик, тортоголик, хлебоголик, чаеголик, чипсоголик, шашльккоголик, шоколадоголик/шокоголик, яблокоголик.

В польском языке изофонный уничижительный аффикс -(o)holik также расширяет свое словообразовательное поле благодаря словотворчеству интернавтов, которые с его помощью образовали более 90 наименований лиц, находящихся в патологической зависимости от своих увлечений, страстей и пороков, ср.: amerykanoholik, angloholik, animeholik, autoholik, baboholik, bankoholik, beatlesoholik, blogoholik, butoholik, ciuchoholik, dietoholik, dyskoholik, erotoholik, estetoholik, euroholik, filmoholik, flirtoholik, forsoholik, fotoholik, gitaroholik, gniewoholik, golfoholik, hazardoholik, infoholik, internetoholik, kasoholik, kinoholik, komórkoholik, komputeroholik, kosmetykoholik, kotoholik, 
książkoholik, kurwoholik, lekoholik, medioholik, morzeholik, motoholik, muzykoholik, narkoholik, naukoholik, nikotynoholik, perfumoholik, pitkoholik, plażoholik, politykoholik, pornoholik, potteroholik, psiakoholik, psychoholik, rapoholik, reklamoholik, robotoholik, rusoholik, rymoholik, seksoholik, serialoholik, siecioholik, sklepoholik, spiskoholik, sportoholik, stresoholik, świnioholik, tatoholik, teleholik, testoholik, torboholik, turoholik, tytonioholik, urlopoholik, wędkoholik, wiedzoholik, zabawoholik, zakupoholik, żartoholik, żonoholik и др.

С помощью поисковой системы Google.pl нами выявлено более 30 неодериватов с финалью -holik - наименований лиц, испытывающих патологическую зависимость от продуктов питания, блюд и напитков, ср.: awokadoholik, bananoholik, chipsoholik, chleboholik, ciastoholik, cukierkoholik, cukroholik, czekoholik/czekoladoholik, frytkoholik, herbatoholik, jabłkoholik, jadtoholik, jogurtoholik, kawoholik, kebaboholik, kefiroholik, kietbasoholik, kwasoholik, makaronoholik, makoholik, marmoladoholik, makoholik, mięsoholik, miodoholik, mlekoholik, pepsiholik, pieczywoholik, piwoholik, pizzaholik, ryboholik, seroholik, stodyczoholik, sokoholik, tortoholik, warzywoholik, whiskoholik, winoholik, wódkoholik, ziemniakoholik, zupoholik и др.

В последние годы в интернет-дискурсе на русском и польском языках появились изофонные названия людей, патологически зависимых от Интернета и его сервисов, ср.: русск. блогоголик, инстаграмоголик, интернетоголик, нетоголик, твиттероголик, фейсбукоголик, форумоголик, чатоголик; польск. blogoholik, czatoholik, facebookoholik/fejsbukoholik, forumoholik, instagramoholik, internetoholik, twitteroholik.

Кроме яркой выразительности, гибридные неодериваты с формантами -(о)голик, -(o)holik несут богатую социально-культурную информацию о ценностных ориентирах носителей русского и польского языков.

\section{Заключение}

Подводя итоги исследования, можно сделать следующие выводы:

1. Гибридные дериваты, созданные с помощью новых интернациональных формантов -инг/-ing, -завp/-zaur, -оид/-oid, -(о)голик/-(o)holik, способны одновременно выполнять несколько функций: а) экспрессивно-декоративную, поскольку служат средством украшения речи; б) людическую - ввиду того, что используются в языковой словообразовательной игре; в) парольно-идентифицирующую - в связи с тем, что дают коммуникантам возможность продемонстрировать свою принадлежность к группе интеллектуально развитых билингвов; г) функцию экономии речевых средств. Продуктивность этих суффик- 
сальных терминоэлементов, способствующих автоматизации процесса словопроизводства, свидетельствует также об усилении агглютинативности в процессе деривационной гибридизации.

2. В русском и польском интернет-дискурсах создание гибридных дериватов с помощью интерморфем -завp/-zaur, -оид/-oid, -(о)голик/ -(o)holik нередко является способом реализации вербальной агрессии, причем речевая практика российских интернавтов отличается более широким набором словообразовательных приемов оскорбления, что, по-видимому, связано с обыденностью инвективного общения в русскоязычном социуме, отражающего деструктивные процессы в области его материальной и духовной культуры.

3. Деривационную активность заимствованных формантов -инг/-ing, -завp/-zaur, -oud/-oid, -(o)zолик/-(o)holik в речевой практике российских и польских интернавтов повышают: а) глобальная интернационализация, поддерживаемая интернетизацией информационного пространства; б) билингвоанглизация; в) лингвокультурная англо-американская мода, способствующая формированию языкового сознания, базирующегося на избыточных заимствованиях и сленге.

\section{Библиография}

Blommaert, Jan, Jie Don. „Language and Movement in Space”. The Handbook of Language and Globalization. Red. Nikolas Coupland. London, Blackwell Publishing, 2010, s. 366-384.

D'âkov, Anatolij, Elena Skvoreckaâ. „Suffiks -ing zavoevyvaet svoi pozicii v russkom slovoobrazovanii”. Sibirskij filologičeskij žurnal, nr 4, 2013, s. 171-183.

Görlach, Manfred, ed. A Dictionary of European Anglicisms: A Usage Dictionary of Anglicisms in Sixteen European Languages. Oxford, Oxford University Press, 2001.

Huizinga, Johan. Homo ludens. Zabawa jako źródto kultury. Per. Maria Kurecka, Witold Wirpsza. Warszawa, Aletheia, 2011.

Kabakči, Viktor V. „Âzyk moj, kamo grâdeši? Globalizaciâ, «globanglizaciâ» i mežkul'turnaâ kommunikaciâ". Âzyk v paradigmah gumanitarnogo znaniâ: XXI vek: sbornik naučnyh statej. Red. Valeriâ E. Černâvskaâ, Suren Zolân. Sankt-Peterburg, Sankt-Peterburgskij gosudarstvennyj universitet èkonomiki i finansov, 2009, s. 78-97.

Kachru, Braj B., ed. The Other Tongue: English Across Cultures. 3rd ed. Oxford-New York, Pergamon Press, 1983.

Korâkovceva, Elena I. Očerki o âzyke sovremennyh slavânskih SMI. Siedlce, Wydawnictwo UPH w Siedlcach, 2016.

Prensky, Marc. Digital Natives, Digital Immigrants. Web. 29.05.2019. www.nnstoy.org/download/ technology/Digital+Natives+-+Digital+Immigrants.pdf.

Vinogradova, Tat'âna. „Specifika obŝeniâ v Internete”. Russkaâ i sopostavitel'naâ filologiâ: Lingvokul'turologičeskij aspekt, nr 11, 2004, s. 63-67.

Waszakowa, Krystyna. Przejawy internacjonalizacji w słowotwórstwie wspótczesnej polszczyzny. Warszawa, Wydawnictwa Uniwersytetu Warszawskiego, 2005. 


\section{Электронные ресурсы и источники}

17marta.ru. Web. 11.04.2018. www.17marta. ru/forum/ index.php? topic $=4980.0$.

Filisof.Livejournal. Web. 21.12.2017. https://filisof.livejournal.com/147832.html.

Free Republic. Web. 12.01.2018. http://freerepublic.com/focus/f-news/2134378/posts.

Harbor.ru. Web. 10.01.2018. http://harbors.ru/journal/journal.php?action=view\& journalid=32008.

Ingi.wadi.pl. Web. 16.04.2018. https://ingi.wadi.pl.

Merriam-Webster Dictionary. Web. 28.04.2019. www.m-w.com.

Pikabu. Web. 17.04.2018. https://pikabu.ru/story/ o_nabolevshem_6011105.

The Spoof! Web. 19.04.2018. http://www.thespoof.com/spoof-news/magazine/3146/washington-dc-paleontology-conference-unveils-new-species. 
